\title{
HEGIS - GIS ZA ZDRAVJE IN OKOLJE
}

\author{
Tadeja Fatur in Metoda Dodič-Fikfak
}

Izvleček

UDK 614:91:681.3

Geografski informacijski sistem, ki združuje podatke s področja zdravstva in okolja (HEGIS), bi olajšal raziskovanje ter načrtovanje in izvajanje politike $v$ javnem zdravstuu in pri varstuu okolja. Slovenija je na začetku uvajanja tega informacijskega sistema.

UDC 614:91:681.3

Abstract

HEGIS - GIS FOR HEALTH AND ENVIRONMENT

A geographical information system combining data on both health and the environment (HEGIS) would facilitate research, policy development and implementation in the fields of public health and environmental quality. Slovenia is at the beginning of the development of this information system.

Ena od pomembnih možnosti uporabe metodologije geografskih informacijskih sistemov (GIS) je tudi $v$ zdravstvu oz. zdravstvenem informacijskem sistemu.

Evropski regionalni urad Svetovne zdravstvene organizacije razvija program informacijskih sistemov za okolje in zdravje. Program naj bi služil kot orodje za oceno tveganja (risk assessment) in za ukrepanje pri tveganju (risk management) na področju Evrope. Del tega programa je tudi Geografski informacijski sistem za zdravje in okolje (Health and Environment Geographical Information System, HEGIS). HEGIS je torej ime za enoten informacijski sistem, $\mathrm{v}$ katerem so podatki iz različnih virov in področij (npr. zdravstva, demografije, okolja) povezani med seboj s pomočjo skupnih standardiziranih geografskih navodil in shranjeni $v$ okolju geografskega informacijskega sistema.

Za vodenje projekta HEGIS je SZO zadolžila svoja Evropska centra za okolje in zdravje $v$ Rimu in $v$ Bilthovnu na Nizozemskem. Centra naj bi us-

Tadeja Fatur, dr. med., Dodič-Fikfak Metoda, dr. med., Univerzitetni zavod za zdravstveno in socialno varstvo, Trubarjeva 2, 61000 Ljubljana 
klajevala uvajanje začetnih programov. Predvsem delo slednjega centra naj bi temeljilo na pilotskih študijah, ki bi bile izbrane po jasno določenih merilih, in na sodelovanju $z$ usposobljenimi tehničnimi centri (kot npr. Nizozemski inštitut za javno zdravstvo in varstvo okolja $v$ Bilthovnu) in drugimi nacionalnimi in mednarodnimi organizacijami, ki že uporabljajo GIS za obravnavanje okolja in zdravja.

Projekt HEGIS ima tri glavne cilje:

1.

- preveriti uporabnost trajnega informacijskega sistema na področju javnega zdravstva in kakovosti okolja za potrebe $\mathrm{SZO}$ in evropskih in nacionalnih agencij, ki se ukvarjajo $s$ politiko razvoja javnega zdravstva in $\mathrm{z}$ vplivom okolja na zdravje ljudi;

- preveriti tehnično izvedljivost uvedbe takega sistema;

- ugotoviti pogoje, ki so potrebni za njegovo izvedbo in delovanje na evropski, nacionalni in subnacionalni ravni;

2.

- priskrbeti informacije, ki bi bile primerne tako za mednarodno in nacionalno politiko kot za raziskave na področju javnega zdravstva in vpliva okolja na zdravje ljudi;

3.

- priskrbeti potrebne informacije za pripravo poročila "Skrb za prihodnost Evrope" ("Concern for Europe's Tomorrow", CET), pri katerem gre za ekološko in zdravstveno napoved, ki vključuje stanje okolja in stanje javnega zdravstva v Evropi.

Seveda je pri načrtovanju, uvajanju in uporabi HEGIS-a pričakovati precej težav. Vsak uspešen GIS zahteva ne le primerno računalniško opremo (hardware in software), ampak tudi zanesljive podatke, učinkovito organizacijsko strukturo in dobro usposobljeno osebje. Vsak od teh faktorjev lahko zavre razvoj kateregakoli GIS programa in še posebej HEGIS-a.

Pravo vrednost HEGIS-a bo mogoče ugotoviti šele takrat, ko bo dovolj razvit in preizkušen.

Tako ekološki kot zdravstveni podatki kažejo prostorsko raznolikost. Številni možni vzročni dejavniki bi utegnili povezovati krajevno ekološko stanje in zdravje; veliko pa je tudi neekoloških dejavnikov, ki so geografsko vezani in lahko prav tako vplivajo na zdravje ljudi.

Ker je vzročno zvezo med povzročiteljem in posledico izjemno težko ugotoviti, se bodo vedno znova postavljala vprašanja: "Kaj pa če je bolezen povzročil nek drug ali stranski dejavnik tveganja?" Gotovo bo HEGIS pokazal področja, kjer bi motnje lahko povzročil ekološki dejavnik, hkrati pa bo zelo koristil pri iskanju časovnih in prostorskih vzorcev $v$ zdravstvenih 
rezultatih ter pri postavljanju hipotez o odnosih med okoljem, demografijo in zdravjem.

GIS je zelo pomemben na področjih

- obravnavanja tveganja pri nesrečah manjšega in večjega obsega (SZO namenja posebno pozornost nesrečam in jih uvršča $\mathbf{k}$ obravnavam problemov okolja.),

- zgodnjega opozarjanja na nevarnosti,

- izbire prednostnih zdravstvenih problemov,

- načrtovanja ekoloških sistemov za vzorčenje in spremljanje ter

- načrtovanja zdravstvenih akcij v smislu zdravja za vse.

HEGIS bo sestavljala mreža nacionalnih centrov. Ta mreža bo oskrbovala osrednjo bazo podatkov $\mathrm{z}$ osnovnimi informacijami o okolju in zdravju in $z$ vrsto kritičnih kazalcev stanja javnega zdravstva in njegove povezave $s$ problemi okolja ter te informacije tudi sama uporabljala.

Slovenija je pri uvajanju HEGIS-a na začetku poti. Po sprejetju v SzO smo kot center SZO za Slovenijo vključeni v projekt CET. Tako bomo lahko aktivno sodelovali pri izgradnji HEGIS-a v Evropi, hkrati pa nas SZO tudi obvezuje, da $\mathrm{v}$ skladu $\mathrm{z}$ njenimi cilji oz. usmeritvijo "Zdravje za vse" uvedemo metode za spremljanje, oceno in nadzorovanje zdravstvenih tveganj $\mathrm{v}$ okolju. Tudi pri nas že dalj časa močno izražena potreba po primerjanju zdravstvenih in večplastnih ekoloških podatkov (npr. o stanju vode, zemlje, zraka, hrane, notranjega bivalnega okolja). Tovrstno primerjanje lahko opozori na vrsto možnih vplivov okolja na zdravje ljudi in nas napoti v natančnejše in bolj usmerjene zdravstveno ekološke raziskave. Tako dobljeni rezultati so izhodišča tako za ustrezno odločanje na področju varovanja zdravja in varstva okolja kot za politiko pri odločanju o varovanju človekovega zdravja in okolja. 